\title{
LPG-truck tanker accident and consequence management during Covid-19 pandemic: A case from India
}

\author{
Ramesh Kumar Behera \\ Directorate of Factories and Boilers, Odisha, India
}

\begin{abstract}
The ever-growing use of liquefied petroleum gas (LPG) for domestic and industrial purposes increased the chances of accidents during transportation. The risk of fire, explosions, and environmental hazards due to LPG- truck tanker mishaps loom large on national highways and their mitigation became a concern during the Covid-19 pandemic. This paper reports on the characteristics of LPG-truck tanker mishaps in India and proposes a revised disaster response model for pandemic scenarios. This study is based on secondary data and field experiments from two real cases in India. We have analyzed fifty LPG-truck tanker incidents during the period 2009-2020, examined the type, distribution, and cause of cases, the influence of weather, engineering and regulatory interventions, and looked at the psychology of first responders in the lockdown phase. We have used R and MS-Excel for data analysis. The study showed that the largest share of accidents (26\%) occurred early in the morning between 4.00-8.00 hours. Cold weather increased the vulnerability with $41 \%$ of cases reported in the winter season. The percentage of incidents resulting in the toppling of tankers was maximum (50\%) followed by collision and equipment failure. The study showed that accidents were less during the Covid-19 pandemic. Defective road design, poor maintenance,
\end{abstract}


and negligent driving increased the accident rate. However, a slowdown in inspection, audit and mock drills was conspicuous which could be detrimental in the long term. The findings of this study and the recommendations such as enforcement of traffic norms, proper road design, and construction, implementation of SOPs and IEC measures, mock exercises, and revised emergency protocols could be helpful for prevention of HazMat-accidents in future.

Keywords: Transportation accident; LPG-truck tanker mishaps; Covid-19 and accident control; Accident and emergency response; Emergency management in India, Regulatory interventions

\section{Introduction}

The increasing use of LPG for domestic and industrial purposes enhanced the vulnerability for accidents during transportation. India is the second-largest consumer of liquefied petroleum gas (LPG) (Gallab et al., 2017, MPNG, 2017). The consequences of LPG truck tanker accidents can be severe and life threatening because of the risk of fire, explosions, and environmental hazards associated with such events (Binder and Sanderson, 1987, Coleman, L., 2006, Kidam et al., 2014, Liu et al., 2020). Fire, explosions, and spillage due to LPGtruck tanker accidents can endanger a large population, cause sickness, injury, loss of life, and damage to the environment (Suruda et al., 1996, Deng et al., 2001, Hu et al., 2004, Takase et al., 2004, Zimmerman et al., 2008). A lot of planning, preparedness and practice is required to secure the population from the wrath of such tragedy and minimize the losses (Ramabrahmam et al., 2000; Moe and Pathranarkul, 2006; Good year, 2009). The United Nations Office for Disaster Risk Reduction (UNDRR) has been providing leadership to nations for emergency management of chemical accidents and industrial disasters. In India, the Disaster Management Act, 2005 provides the necessary legal mandate for mitigation of chemical accidents and disasters (www.ndma.gov.in). The Covid-19 pandemic in 2020 came with an unprecedented public health emergency. Responding to a major accident during this pandemic became difficult due to the lack of Covid appropriate protocols in existing emergency response plans (Varotsos and Krapivin, 2020, Haghani et al., 2020). Against this background, the present study reports on LPG-tanker accidents in India, examines the distribution and cause of accidents, the influence of weather, investigates the impact of the 
pandemic on consequence management; and proposes a revised model for emergency management for pandemic scenarios based on learning from field experiments.

The marketing of LPG is regulated by the Bureau of Indian Standards (BIS 4576:1999). An LPG-truck tanker consists of a cabin and a bullet-mounted carrier to hold 18MT of product. An accident involving LPG-bullets can end up in boiling liquid expanding vapor explosion (BLEVE) or vapor cloud explosion (VCE). BLEVE is a combination of fire and explosion with intense radiant heat emission within relatively short time intervals, and it manifests in shock wave propagation, fireball radiation, and fragment projection. According to Sellami et al., 2018, BLEVE takes place due to the failure of a vessel or container with liquid at a temperature considerably higher than its boiling point at atmospheric pressure. Whenever a large quantity of flammable or explosive material is released from a vessel and accumulates in the open space, it forms a cloud and moves in the direction of the wind. The vapor cloud catches fire upon contact with a source of ignition and releases energy in the form of a blast wave. This phenomenon is known as a vapor cloud explosion (Zhu et al., 2017). The damage distance can be predicted with help of different software by using parameters such as time of occurrence, size of leak-hole, wind speed, duration of exposure (Hanna et al., 1991, Hoalst-Pullen 2011). A SAFETI simulation of a full LPG-bullet accident shows that the damage distance can be as high as 258 meters from the source of leakage in a BLEVE scenario (www.dfbodisha.gov.in). The consequences of such mishaps can be controlled provided the initial response is quick and carried out according to the pre-decided emergency response plans (Lindell and Perry, 1998, Othman and Beydounn, 2013, AlDahash et al., 2018).

The State of Odisha on the eastern coast of India is a steel hub of South East Asia with 4500 factories, 2500 boiler plants. It has one 15 MTPA capacity Oil Refinery, five Integrated Steel Plants, two Fertilizer Complexes, dozens of Power-generating units, and four LPG bottling plants (www.dfbodisha.gov.in; Gupta et al., 2010, Behera and Hassan, 2019 ). On average 500, LPG-truck tankers commute every day using various highways through the State. The State Government has been recognized for its progress in disaster preparedness and mitigation capability. The State of Odisha (India) witnessed several LPG truck tanker accidents in past and successfully mitigated the events (Behera and Hassan, 2017). In this paper, we attempt to understand the characteristics of LPG-truck tanker mishaps, the influence of weather and examine the impact of the Covid-19 pandemic on emergency response actions based on two real case studies from India. 


\section{Materials and Methods}

The research design is exploratory, descriptive, and qualitative. The research is based on secondary data and field experiments in the State of Odisha in India (Figure 1). Secondary data were collected from Public authorities, media reports and Google search for the period 2009-2020. Literature research was carried out through journal, book and electronic media to have an understanding of methods and practices, and evaluate the appropriateness of variables to be considered with implication. For this study we have investigated fifty LPGtruck tanker incidents; examined the type and distribution of accidents, the influence of weather; analyzed two real case studies, interviewed first responders and looked at response actions by various agencies in the pandemic phase. Field experience of authors was incorporated wherever possible. Face-to-face interviews and telephonic discussions were carried out with first responders and Government officials. Software such as R and MS-Excel were used for data analysis.

Figure 1: Study area

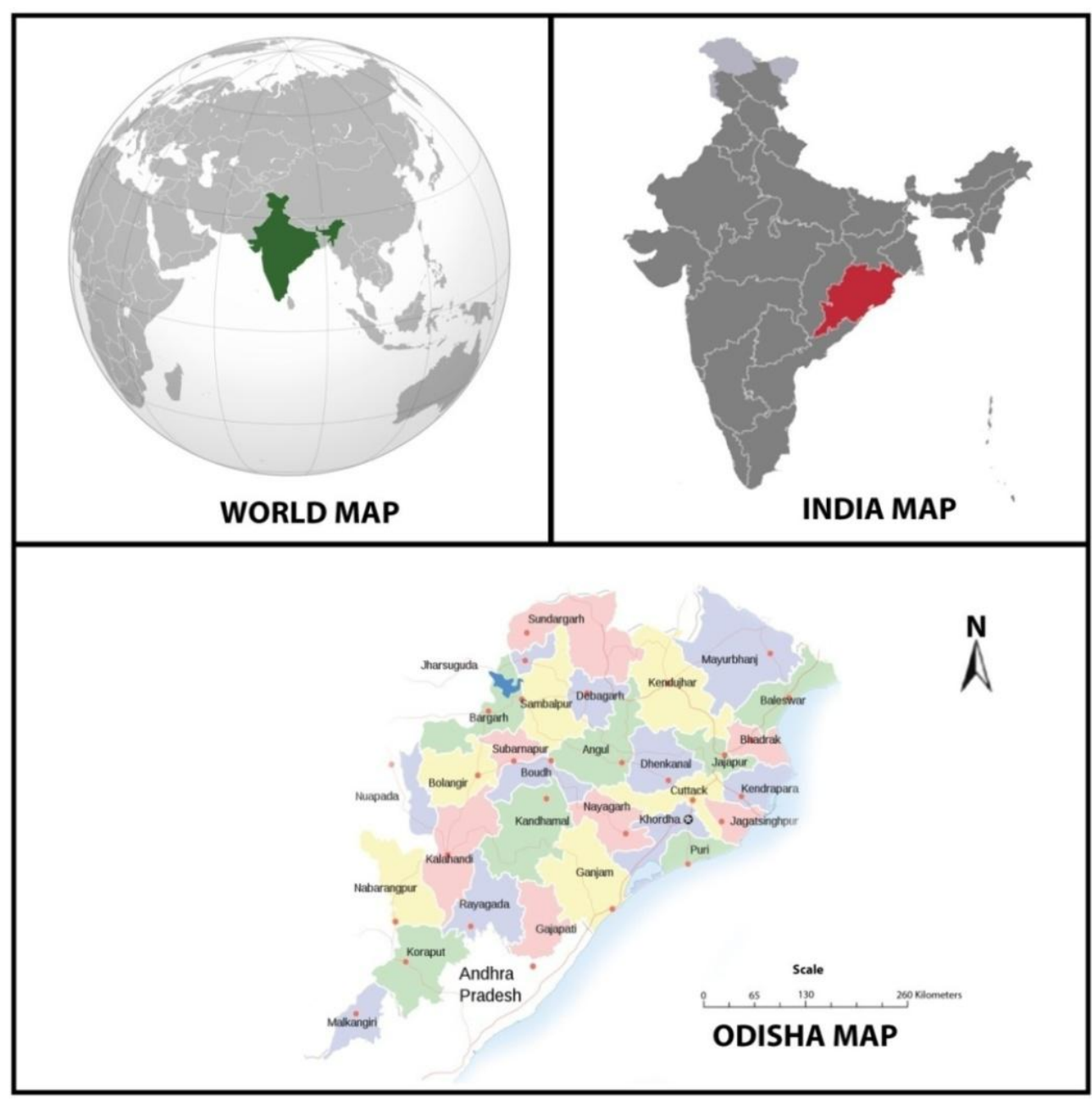




\section{Results}

The distribution of LPG-tanker accidents in different states of India during the period 20092020 is shown in Figure 2. According to the analysis, $14 \%$ of total incidents occurred in the state of Odisha next to Kerala (20\%) and Karnataka (16\%) respectively. This is due to the daily movement of 300-500 numbers of LPG-tankers per day from the oil refinery situated at the port town of Paradeep (India).

Figure 2: LPG truck tanker accidents in India (2009-20).

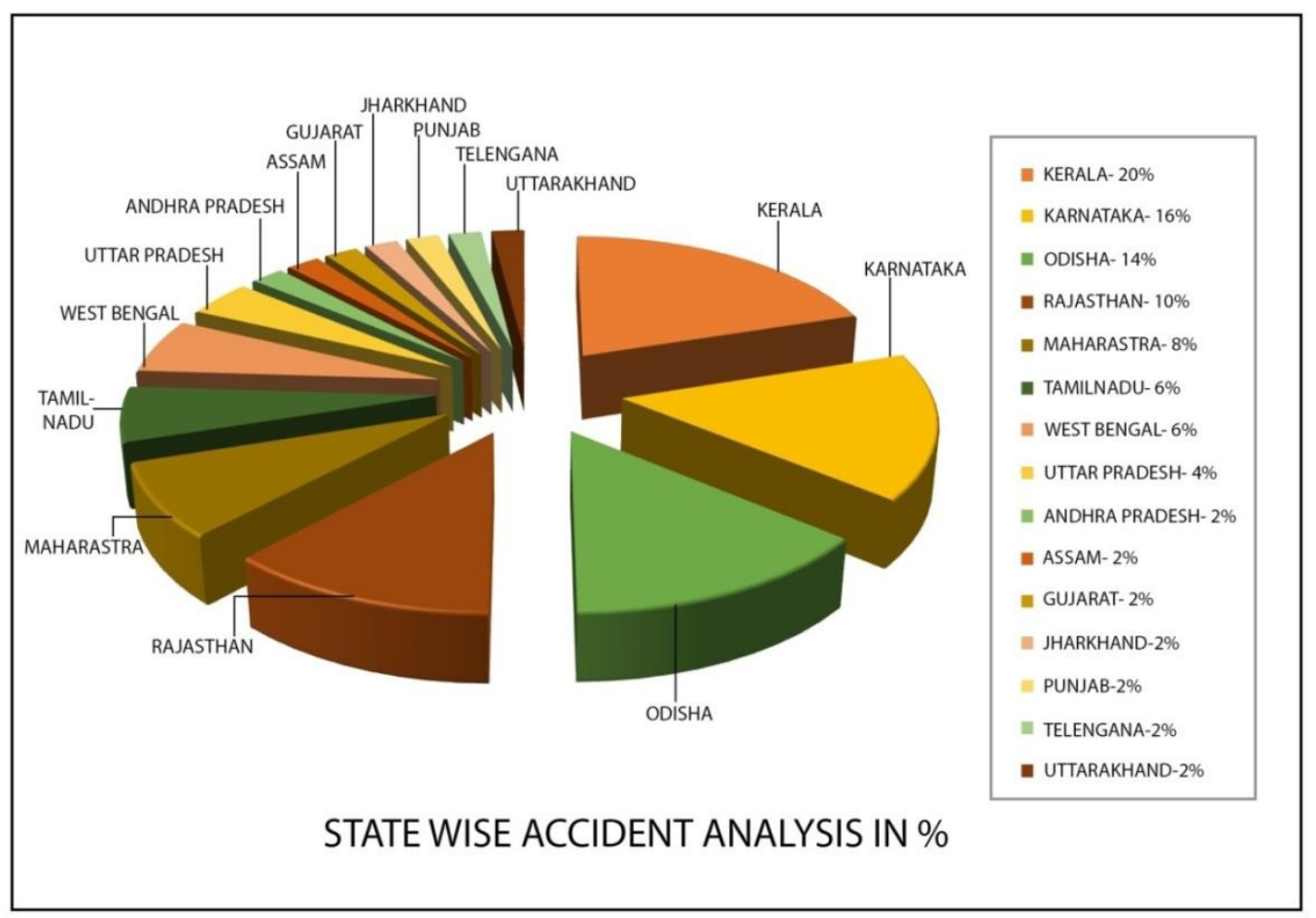

The distribution of type of LPG-tanker accidents in different states of India during the period 2009-2020 is shown in figure 3. On examination, it is revealed that the truck tankers toppled after the accident in the majority of cases (50\%). This is followed by collision with other vehicles (26\%), dashing with divider (6\%), and dashing with level crossing (6\%) respectively. Accidents due to failure of equipment such as malfunction, bursting of tyre, brake failure, the passing of safety relief valve were found to be least (2\%). The study further revealed that under the category 'dashing with other vehicles' $16 \%$ were heavy vehicles whereas $10 \%$ were two-wheelers. The study revealed that over speeding and error in judgment by drivers contributed to $80 \%$ of accidents. Investigation reveals that defective road design, nonavailability of crash barriers, inadequate road shoulder, lack of proper road signage, rash and negligent driving, sudden failure in braking, steering, and suspension system are factors responsible for toppling of tankers. Overturn of tankers generally takes place while 
maneuvering curves. Similarly over speeding, rash driving, poor road condition, error in judgment and lack of experience of the driver, distraction, and violation of traffic rules leads to a collision which mostly takes place in a straight patch of road. Poor illumination and inadequate visibility were reasons for accidents near railway crossings.

Figure 3: Accident type (2009-20)

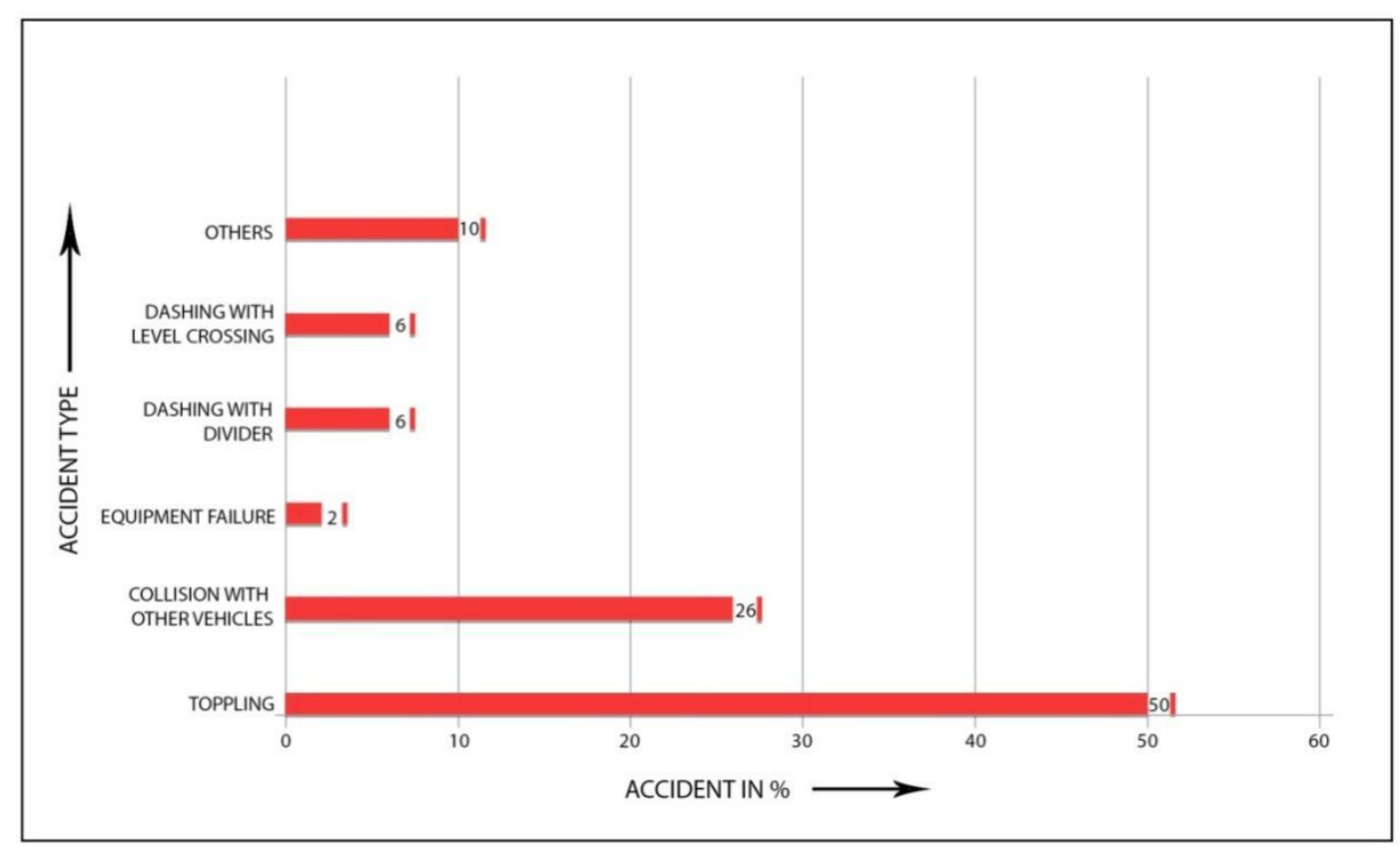

Figure 4 represents the distribution of accidents in different time zones in a day, different days in a week, month, and year. If the unusual spike in 2019 is ignored, the annual rate of accidents between 2009 and 2018 showed an increasing trend up to 2015 and a steady decline is noticed by end of 2018. While the rise from 2009 up to 2015 could be a reflection of increasing demand for LPG in the post-liberalization phase, the decline thereafter may be due to the consolidation of road traffic enforcement measures. On further examination of the same, it is noticed that maximum accidents (26\%) occurred during early morning hours between $4.00-8.00 \mathrm{hrs}$. This could be because of fatigue, distraction, and sleep deprivation by drivers. The period between $12.00-16.00 \mathrm{hrs}$ during daytime was found to be safe with the lowest rate of accident. It is noticed that the maximum number of accidents took place in January (18\%) whereas it was minimum in May (2\%). 
Figure 4: Distribution of LPG-truck tanker accidents in India (2009-20)

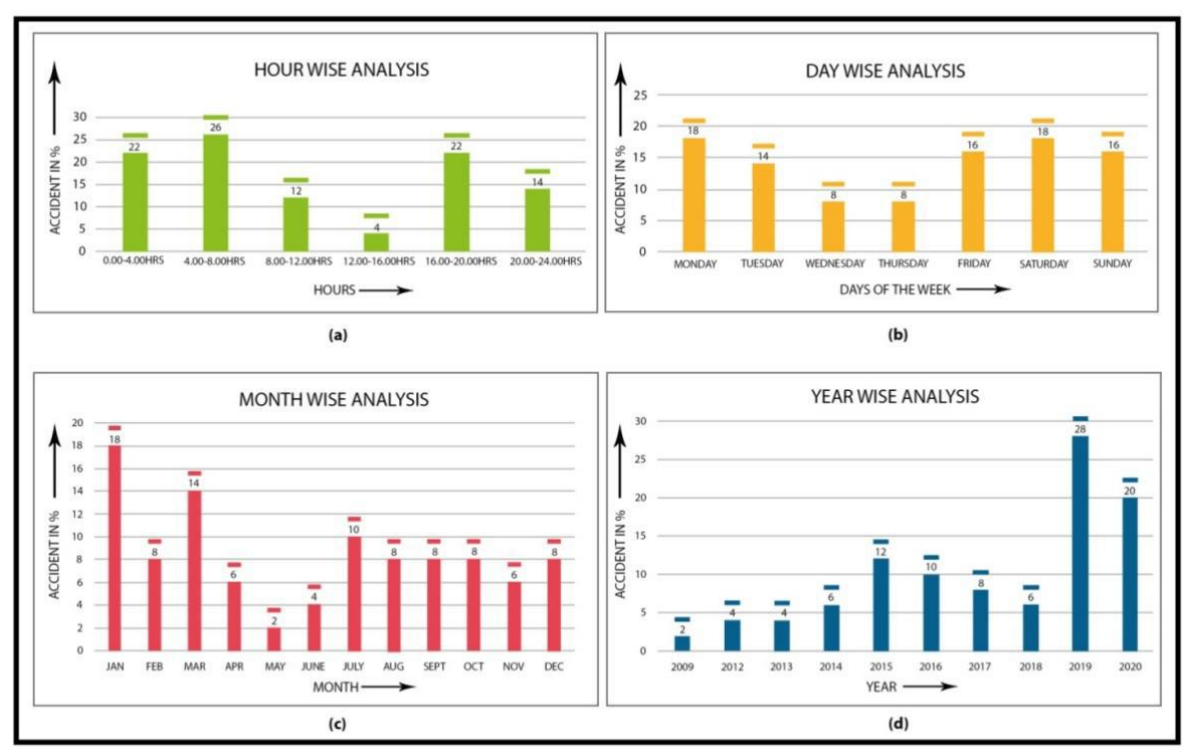

Figure 5 represents the distribution of accidents during the summer, winter, and rainy seasons in India. Maximum cases were reported in winter (41\%) as compared to rainy $(33 \%)$ and summer season (26\%). The day-wise analysis revealed that more accidents took place during the weekdays Friday-Saturday-Sunday-Monday-Tuesday-Wednesday- Friday as compared to Tuesday- Wednesday -Thursday. The period between November and February is cold in India when the demand for LPG is more and visibility due to fog is another challenge confronted by drivers. Fog forms a thin layer of water between tire and road and creates a directional instability called hydroplaning. This phenomenon increases the vulnerability of accidents.

Figure 5: Season wise distribution of accidents in India (2009-20)

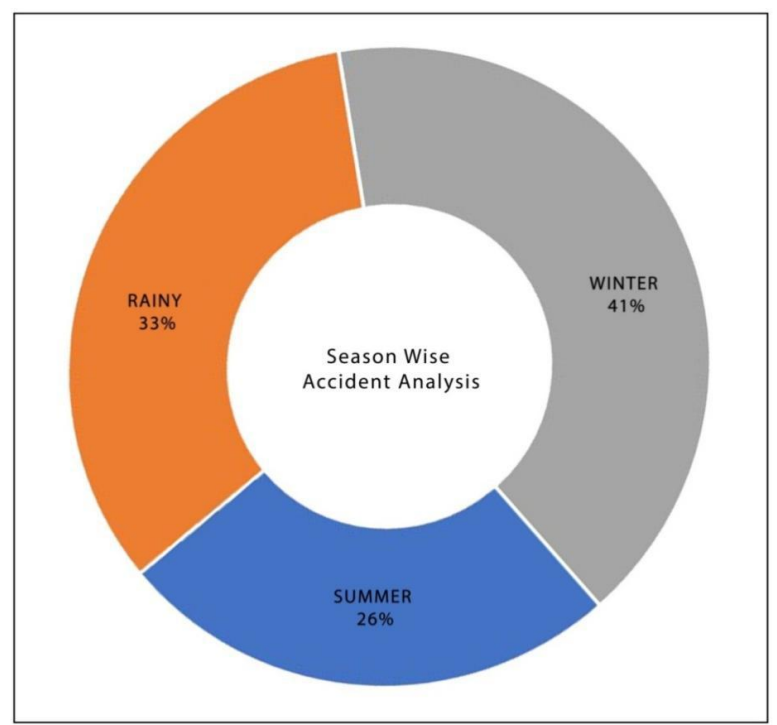


Analysis of cases in this study showed that the top three factors in LPG-truck tanker accidents were defective road engineering and construction, rash and negligent driver behavior, and sudden equipment failure. The top three types of accidents were toppling, collision, and equipment failure. Non-availability of crash barriers, inadequate road shoulder, lack of proper road signage, rash and negligent driving, sudden brake failure, steering, and suspension system resulted in the toppling of tankers. The braking system played a critical role in vehicle safety, and the lack of maintenance of braking components increased the chances of incidents. According to this study, the toppling of tankers took place while maneuvering curves. A collision occurred in a straight patch of the road due to over speed, rash driving, poor road condition, error in judgment and lack of experience of the driver, distraction, and violation of traffic rules. Poor illumination and inadequate visibility were responsible for accidents near railway crossings. Khanzode et al., 2012 introduced a concept of engineering, behavioral, and regulatory countermeasures for accidents, and a set of preventive measures are illustrated in Table 1 to control truck tanker mishaps on highways.

Table 1: Counter-measures for truck tanker accidents

\begin{tabular}{|c|c|c|}
\hline \multirow{2}{*}{ Type of Accident } & \multicolumn{2}{|c|}{ Interventions (Khanzode et al., 2012) } \\
\hline & Engineering & Behavioral and regulatory \\
\hline $\begin{array}{l}\text { Toppling } \\
\text { of tanker }\end{array}$ & $\begin{array}{l}\text { Proper road engineering and } \\
\text { construction; provision of crash } \\
\text { barriers and road shoulder, display of } \\
\text { legible florescent road signage near } \\
\text { curves, U-turns, narrow roads, } \\
\text { bridges; timely detection and } \\
\text { rectification of potholes, blind spots; } \\
\text { eliminate undesirable large humps and } \\
\text { speed breakers. }\end{array}$ & $\begin{array}{l}\text { Prohibiting rash and negligent driving with } \\
\text { strict enforcement measures, ensuring } \\
\text { periodical and preventive maintenance to } \\
\text { eliminate chances of sudden failure in } \\
\text { braking, steering and suspension system; } \\
\text { training of drivers and transporters, traffic } \\
\text { personnel; adequate signage and signaling } \\
\text { on road under construction. }\end{array}$ \\
\hline Collision & $\begin{array}{l}\text { Explore the possibility of bypass roads } \\
\text { and fly over to avoid traffic near } \\
\text { cities; proper maintenance of road and } \\
\text { bridges, Provision of proper } \\
\text { illumination, boom barriers and } \\
\text { signaling system near railway } \\
\text { crossings; display of road safety } \\
\text { signage }\end{array}$ & $\begin{array}{l}\text { Regulate speed; surveillance on rash } \\
\text { driving, periodical training for drivers; } \\
\text { transparency and prudence while granting } \\
\text { license for driving truck tankers; provision } \\
\text { of restroom along the national highway; } \\
\text { Random check to identify drivers with poor } \\
\text { vision, doubtful health conditions; } \\
\text { community awareness programs. }\end{array}$ \\
\hline Equipment failure & $\begin{array}{l}\text { Selection of quality fittings and } \\
\text { mountings used in bullets and those } \\
\text { used in the braking, steering, and } \\
\text { suspension system of a truck tanker. }\end{array}$ & $\begin{array}{l}\text { Periodical audit and maintenance of } \\
\text { braking, steering, and suspension system, } \\
\text { timely lubrication of bearings, checklist } \\
\text { inspection of mountings and fittings; } \\
\text { accountability for lapses. }\end{array}$ \\
\hline
\end{tabular}


Case Studies: Ten LPG truck tanker accidents are shown in Table 2 out of which two cases those took place after the Covid-19 pandemic are illustrated to demonstrate the enormity of problem.

Table 2: LPG truck tanker accidents (2019-20)

\begin{tabular}{|c|c|c|c|c|}
\hline Sl. No & Date/ Time & Place of accident & Nature of incident & Consequences \\
\hline 1 & 21.3.2019/? & $\begin{array}{l}\text { Sagar, Shivamoga } \\
\text { Karnatak, India }\end{array}$ & $\begin{array}{l}\text { Head on collision of } \\
\text { LPG-tanker }\end{array}$ & $\begin{array}{l}\text { Two drivers, and one } \\
\text { helper died, traffic } \\
\text { disrupted }\end{array}$ \\
\hline 2 & $\begin{array}{c}2.08 .2019 / \\
12 \text { noon }\end{array}$ & $\begin{array}{c}\text { NH75, Renkya } \\
\text { Karnataka, India }\end{array}$ & $\begin{array}{l}\text { LPG tanker overturned } \\
\text { on National Highway }\end{array}$ & $\begin{array}{c}\text { Driver injured, gas } \\
\text { leakage, traffic disrupted }\end{array}$ \\
\hline 3 & $\begin{array}{c}31.8 .2019 / \\
8 \mathrm{AM}\end{array}$ & $\begin{array}{l}\text { NH46, Pellikonda } \\
\text { Chennai, India }\end{array}$ & $\begin{array}{l}\text { LPG Tanker toppled on } \\
\text { the highway }\end{array}$ & $\begin{array}{l}\text { Traffic disrupted for four } \\
\text { hours. }\end{array}$ \\
\hline 4 & $16.10 .2019 / ?$ & $\begin{array}{c}\text { NH } 66 \\
\text { Mangaluru, India }\end{array}$ & $\begin{array}{l}\text { LPG tanker toppled on } \\
\text { road }\end{array}$ & $\begin{array}{c}\text { Gas leakage, evacuated } \\
\text { in one KM radius }\end{array}$ \\
\hline 5 & $\begin{array}{c}10.11 .2019 / \\
10.45 \mathrm{PM}\end{array}$ & $\begin{array}{l}\text { State Highway } \\
\text { Mathura, India }\end{array}$ & $\begin{array}{l}\text { Empty LPG tanker } \\
\text { rammed with railway } \\
\text { gate }\end{array}$ & $\begin{array}{l}\text { One fatal, } 4 \text { injured. Rail } \\
\text { traffic affected }\end{array}$ \\
\hline 6 & $\begin{array}{l}14.12 .2019 / \\
4.30 \mathrm{AM}\end{array}$ & $\begin{array}{c}\text { NH55, Sambalpur } \\
\text { Odisha, India }\end{array}$ & $\begin{array}{l}\text { Head on Collision of } \\
\text { LPG Tanker with truck }\end{array}$ & $\begin{array}{c}2 \text { drivers burnt to death. } \\
\text { Traffic disrupted for two } \\
\text { days }\end{array}$ \\
\hline 7 & $\begin{array}{l}11.1 .2020 / \\
4.30 \mathrm{AM}\end{array}$ & $\begin{array}{c}\text { NH53, Badchana } \\
\text { Odisha, India }\end{array}$ & $\begin{array}{l}\text { LPG Tanker toppled on } \\
\text { National Highway }\end{array}$ & $\begin{array}{c}\text { No Casualty, Traffic } \\
\text { disruption }\end{array}$ \\
\hline 8 & $\begin{array}{l}\text { 20.03. 2020/ } \\
10 \mathrm{PM}\end{array}$ & $\begin{array}{l}\text { NH66, Mallapuram, } \\
\text { India }\end{array}$ & $\begin{array}{l}\text { Overturning of LPG } \\
\text { Tanker (IOCL ) at a } \\
\text { curve }\end{array}$ & $\begin{array}{l}\text { Diver injured; traffic } \\
\text { stopped for many hours }\end{array}$ \\
\hline 9 & $\begin{array}{c}19.04 .2020 \\
7.30 \mathrm{AM}\end{array}$ & $\begin{array}{c}\text { NH-16 } \\
\text { Bhubaneswar }\end{array}$ & LPG tanker toppled & $\begin{array}{l}\text { Driver injured, traffic } \\
\text { disrupted for four hours }\end{array}$ \\
\hline & $\begin{array}{c}20.04 .2020 / \\
3.30 \mathrm{AM}\end{array}$ & $\begin{array}{l}\text { Bariniput, Koraput. } \\
\text { Odisha, India }\end{array}$ & $\begin{array}{l}\text { Overturning of LPG } \\
\text { Tanker (IOCL ) at curve }\end{array}$ & $\begin{array}{c}\text { Traffic stopped for many } \\
\text { hours }\end{array}$ \\
\hline 10 & 26.09.2020 & $\begin{array}{l}\text { Managalore } \\
\text { India }\end{array}$ & $\begin{array}{l}\text { Toppling of a BPCL LPG } \\
\text { tanker on NH-66 }\end{array}$ & $\begin{array}{c}\text { Gas leakage, } \\
\text { traffic disrupted }\end{array}$ \\
\hline
\end{tabular}

\section{SOURCE: GOOGLE.COM (?: NOT AVAILABLE)}

\section{Case study 1, April 19, 2020, National Highway, Bhubaneswar, India:}

LPG tanker that started from Visakhapatnam and traveling towards a bottling plant at Bhubaneswar (India) overturned on a National highway at around 7 AM on a Sunday. The reason for the accident was the loss of balance and error of judgment by the driver. The incident occurred barely $30 \mathrm{~km}$ away from the bottling plant. On getting information from 
eyewitnesses from a nearby village, the police reached the accident site first and informed the LPG-bottling plant situated in the vicinity. Soon other agencies from fire services, district administration, factory inspectorate, transport department reached the spot for the rescue operation. Cranes were mobilized. The technicians and officials of the bottling plant also reached within half an hour and activated the district emergency response plan. At the outset, the possibility of leakage from the bullet was checked. After confirmation of no gas leakage, the tanker was turned upright with the help of three hydra cranes and taken to the bottling plant for transfer of liquid under the supervision of experts. All the officials engaged in the operation used nose masks and maintained social distance norms. There was no casualty in this case.

\section{Case study 2, April 20, 2020, National Highway, Bariniput, India:}

An LPG-truck tanker with 17 tones of propane gas overturned on the National Highway in Koraput district on a Tuesday morning, disrupting vehicular traffic for several hours. The incident took place while maneuvering a curve in hilly terrain. The driver sustained minor injuries. The Police were informed by local people who reached the site with representatives of the fire department within an hour. Officials from administration, revenue, transport department, factory inspectorate, and pollution control and electronics media reached the spot. Technical experts from nearby industries reached the site with protective gear, cranes, and fire tender. The police team stopped traffic movement on either side. The tanker was put back on the road with the help of one crane and two hydra machines after an hour-long effort. Several goods vehicles were stranded on both sides of the road for long hours till the completion of the exercise. It took 18 hours to restore traffic movement. Inter-departmental coordination was fairly good and the seriousness to close the operation was evident as everybody wanted to go back home at the earliest. The efforts for adherence to Covid protocols concerning social distancing, use of mask and gloves were seen more among officers as compared to operators, technicians who are directly associated with mitigation efforts.

Both the case studies relate to the lockdown period. Both the incidents were managed by authorities successfully, but experiences were different. The interview with the first responders and study of cases demonstrated a certain amount of psychological pressure on the public as well as state authorities. The observations during accident response are illustrated in Table 3. 
Table 3: Truck-tanker accident and accident response

\begin{tabular}{|c|c|c|}
\hline \multirow[b]{2}{*}{ Emergency responders } & \multicolumn{2}{|c|}{ Impact of Covid-19 pandemic on emergency response. } \\
\hline & Role of responders & $\begin{array}{c}\text { Experience during } \\
\text { real accident scenarios }\end{array}$ \\
\hline $\begin{array}{l}\text { The district emergency } \\
\text { authority and revenue } \\
\text { officials }\end{array}$ & $\begin{array}{l}\text { Overall coordination and law and } \\
\text { order administration, } \\
\text { communication with press, media } \\
\text { and higher authorities, prohibit } \\
\text { cooking in the affected area, } \\
\text { mobilize cranes and safety gear for } \\
\text { disaster response, and conduct } \\
\text { mock drills in peace time. }\end{array}$ & $\begin{array}{l}\text { A psychological fear for the Covid-19 } \\
\text { pandemic was evident from the body } \\
\text { language of all responders. Inter- } \\
\text { departmental coordination was fairly } \\
\text { good though the certain amount of } \\
\text { difficulty in mobilizing PPE Kits was } \\
\text { noticed. }\end{array}$ \\
\hline Police & $\begin{array}{c}\text { Law and order enforcement, traffic } \\
\text { control, rescue, containment of site, } \\
\text { coordination with fire team, public } \\
\text { contact. }\end{array}$ & $\begin{array}{l}\text { Puplic and vehicular traffic on road was } \\
\text { less, hence not much of difficulty in } \\
\text { law enforcement. Daily press briefing } \\
\text { on TV and social media created } \\
\text { awareness. Police was people friendly. }\end{array}$ \\
\hline Fire officers & $\begin{array}{l}\text { Fire fighting, rescue, cooling of } \\
\text { hazardous installations in the } \\
\text { vicinity, water blanketing to } \\
\text { contain spread of hazardous vapor, } \\
\text { neutralization of site in event of } \\
\text { contamination, identifying water } \\
\text { sources, }\end{array}$ & $\begin{array}{l}\text { The fire department was the first } \\
\text { responder in both the cases. Exposure } \\
\text { to natural and manmade disasters and } \\
\text { mock drills in past provided confidence } \\
\text { to deal with such mishaps. }\end{array}$ \\
\hline Factory Inspector & $\begin{array}{l}\text { Provide technical support and } \\
\text { guidance for controlling and } \\
\text { reducing impact of accident, } \\
\text { coordination with Govt. agencies } \\
\text { and industry experts, advice on } \\
\text { personal protective gear. }\end{array}$ & $\begin{array}{l}\text { Played crucial role in both events. } \\
\text { There was a slowdown in inspection } \\
\text { and audit, mock drills, training, and } \\
\text { awareness programs and the } \\
\text { inspectorate expressed concern as the } \\
\text { district level emergency response } \\
\text { centers (ERC) were still not equipped } \\
\text { adequately to deal with chemical } \\
\text { accidents. }\end{array}$ \\
\hline $\begin{array}{c}\text { Road Transport } \\
\text { Authorities }\end{array}$ & $\begin{array}{l}\text { Provide vehicles required for } \\
\text { evacuation, movement of affected } \\
\text { persons for medical treatment, } \\
\text { investigation in case of } \\
\text { transportation accident. }\end{array}$ & $\begin{array}{l}\text { The drivers of truck tankers showed } \\
\text { patience and resilience and did not } \\
\text { abandon the vehicle after the mishaps } \\
\text { which indicated the training and } \\
\text { awareness measures in past worked } \\
\text { during crisis situations. }\end{array}$ \\
\hline $\begin{array}{l}\text { Health Department } \\
\text { officials }\end{array}$ & $\begin{array}{l}\text { Render first aid, medical care for } \\
\text { affected persons, arrange } \\
\text { ambulance, and carry out post- } \\
\text { mortem of dead body. }\end{array}$ & $\begin{array}{l}\text { First aid was available in time. The } \\
\text { majority of resources were focused on } \\
\text { Covid care. }\end{array}$ \\
\hline $\begin{array}{c}\text { State Pollution Control } \\
\text { Board }\end{array}$ & $\begin{array}{l}\text { Provide technical support and } \\
\text { guidance for controlling and } \\
\text { reducing impact of accident with } \\
\text { regard to environmental } \\
\text { regulations. }\end{array}$ & $\begin{array}{l}\text { Arranging personal protective gear, } \\
\text { nose masks, hand gloves, self- } \\
\text { containing breathing apparatus, canister } \\
\text { masks, and sanitizer was a challenge. }\end{array}$ \\
\hline
\end{tabular}


Non-Governmental organizations, Print and electronic media.
Assist in evacuation, rescue, and relief; carry out IEC programs and participate in mock drills during peace time.
The NGO organizations were occupied with Covid-19 responsibilities. Both cases got wide coverage in print and electronic media.

\section{Discussion:}

The transportation of hazardous materials increased considerably on highways with the economic and industrial growth, and so did the trend of the accidents. Accident due to LPG tankers on highway has been a concern due to growing urbanization in India and the thick population and traffic during peak hours of day. An accident in LPG truck tanker with 18 MT product resulting in boiling liquid expanding vapour explosion (BLEVE), the radiation radii and explosion over pressure is demonstrated in Figure 6 [ Fig. X and Fig. Y] based on dispersion modeling carried out using SAFETI software. The area shown in yellow, green and blue circles respectively indicate severe, moderate and low damage zones. It is noticed that that distance up to $258 \mathrm{~m}$ from the point of accident is susceptible to moderate damage. Such information is extremely important to work out emergency management plan along the route used frequently by LPG tankers. The physical impact of explosion over pressure and heat radiation are shown in Table 4 and Table 5 respectively.

Figure 6 [X: Radiation radii; Y: Explosion overpressure radii]

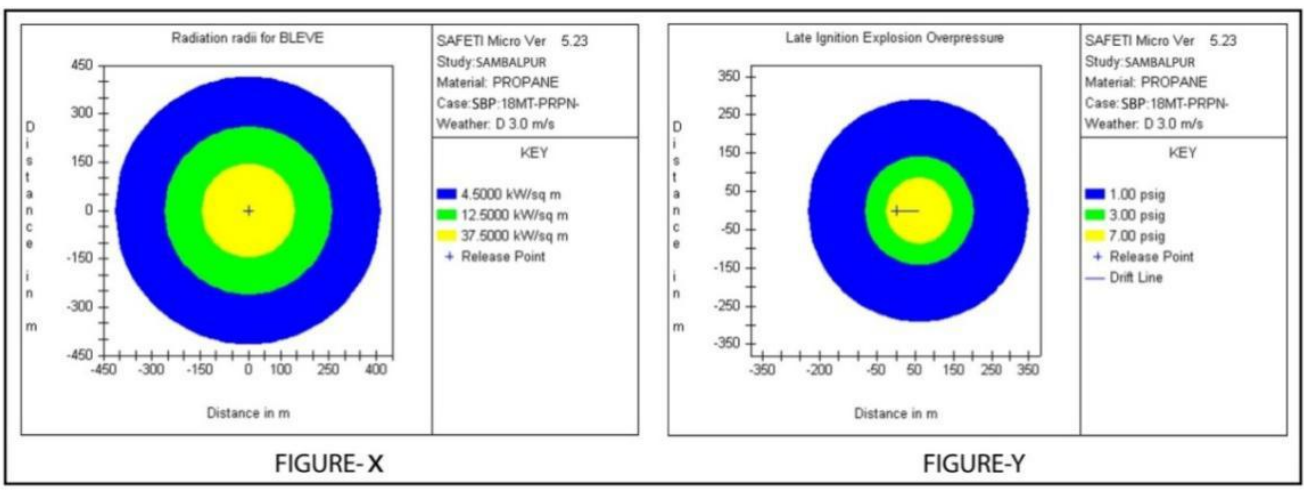

Source: Directorate of Factories and Boilers, Odisha

Table 4: Physical impact of explosion overpressure

Pressure (psig)

0.1

0.7
Damage produced by blast

Breakage of small windows under strain

Minor damage to house structures 


\begin{tabular}{|cl|}
\hline 1.0 & Partial demolition of houses, made uninhabitable \\
\hline 2 & Partial collapse of walls and roofs of houses \\
\hline 3 & $\begin{array}{l}\text { Heavy machines (3000 lb) in industrial building suffered little damage; steel frame } \\
\text { building distorted }\end{array}$ \\
\hline 4 & Cladding of light industrial buildings get ruptured \\
\hline 5 & Wooden utility poles get snapped \\
\hline 7 & Loaded train wagons overturned \\
\hline 10 & Probable total destruction of buildings; \\
\hline 300 & Limit of crater lip \\
\hline
\end{tabular}

Source: Directorate of Factories and Boilers, Odisha

Table 5: Physical Impact of heat radiation

\begin{tabular}{|cl|}
\hline $\begin{array}{c}\text { Radiation level } \\
\left(\mathrm{kW} / \mathrm{m}^{2}\right)\end{array}$ & \multicolumn{1}{c|}{ Observed effect } \\
\hline 37.5 & Sufficient to cause damage to process equipment and human death. \\
\hline 25 & Minimum energy required to ignite wood at indefinitely long exposures (non-piloted) \\
\hline 12.5 & $\begin{array}{l}\text { Minimum energy required for piloted ignition of wood, melting of plastic tubing, } 50 \% \\
\text { damage level }\end{array}$ \\
\hline 9.5 & Pain threshold reached after 8s; second degree burns after 20 seconds \\
\hline 4 & $\begin{array}{l}\text { Sufficient to cause pain to personnel if unable to cover the body within 20 seconds; } \\
\text { however blistering of the skin (second degree burns) is likely; with no lethality }\end{array}$ \\
\hline 1.6 & Will cause no discomfort for long exposure \\
\hline
\end{tabular}

Source: Directorate of Factories and Boilers, Odisha

The severity of LPG-tanker accidents due to toppling, collision with other vehicles, dashing with dividers etc. can be different based on location, nature of terrain, density of population and road traffic. The emergency response action shall accordingly vary. A typical pictorial demonstration of accident, response preparedness is shown in figure 7. According to the study consequences of lpg-tanker mishaps were also dependent on the health of the driver after the incident, the number of vehicles involved in the incident, and the time taken to initiate rescue operations. 


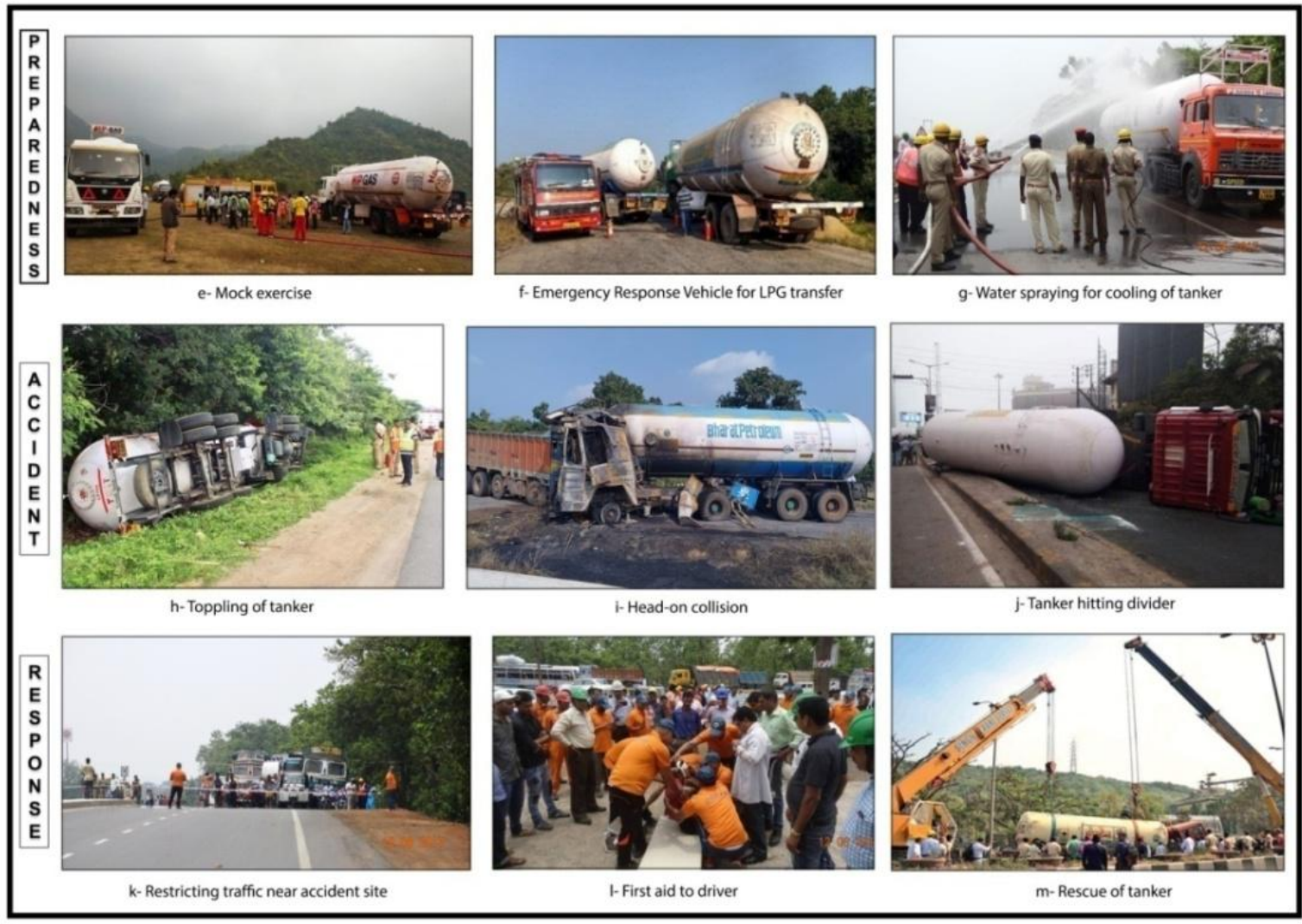

The first step after occurrence of LPG tanker mishap is to activate the emergency response plan and take steps based on experience gathered during pre-disaster preparedness phase. Emergency response means activation of the emergency response plans; evaluating consequence in terms of leakage, fire, explosion, heat radiation, overpressure, and intoxication, take appropriate corrective measures for control, reduction, and transfer of risk; evacuating people; regulating traffic, arranging first aid and medical care, arranging protective gears for first responders, carry out rescue, relief, coordination and networking, and law and order management. According to Mojtahedi and LanOo, 2017 there are four phases in the management of major accident and disasters i.e. mitigation, preparedness, response, and recovery. 


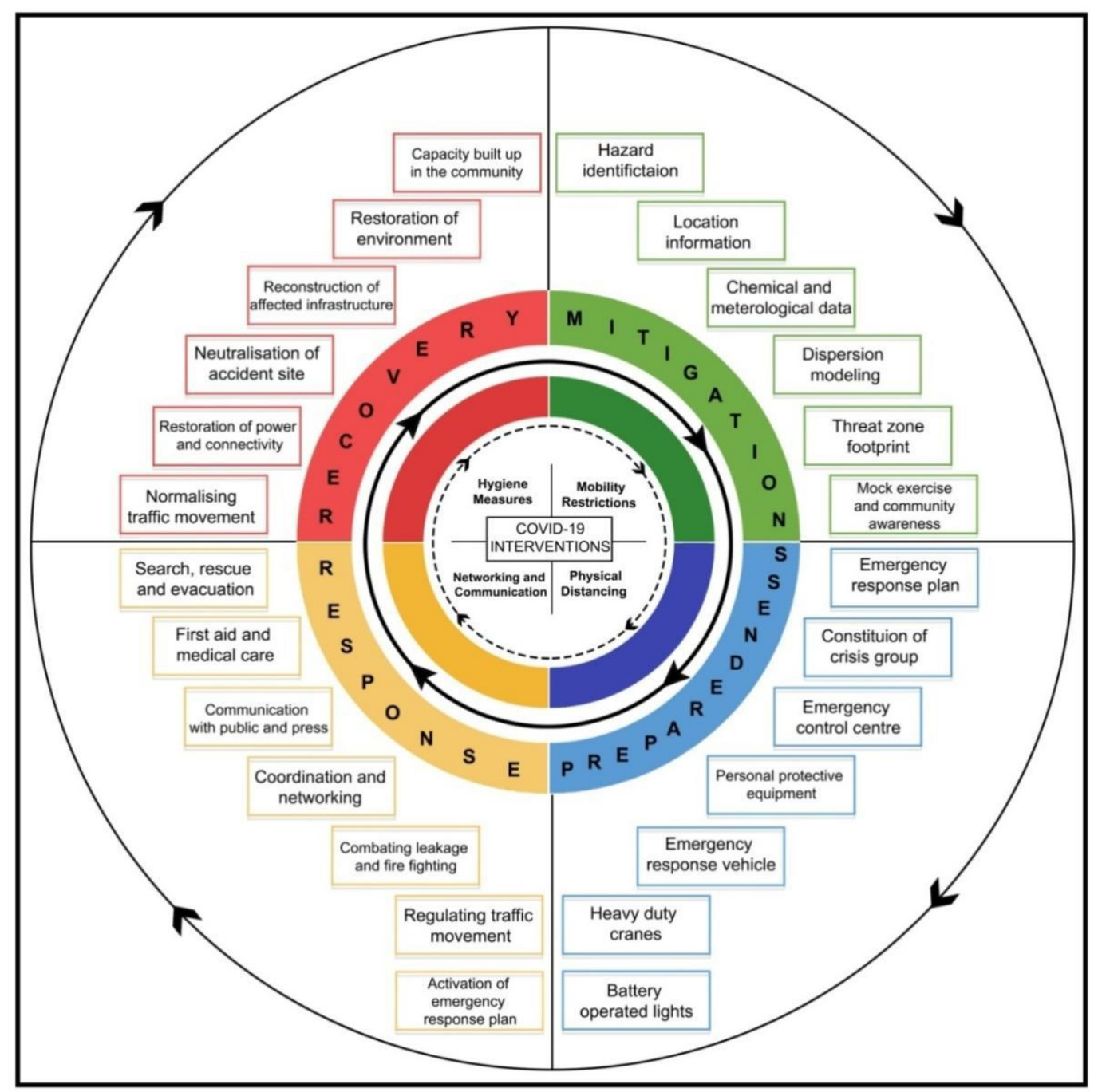

Source: Adopted and improvised based on Mojtahedi and Lan Oo, 2017

4.1.1 Mitigation: Mitigation measures are those taken to limit the adverse consequences of hazards and refer to activities that eliminate and reduce the vulnerability and impact if a disaster strikes. It includes hazard identification, location information, chemical, and meteorological data, dispersion modeling, ascertaining threat zone footprint, mock exercise, and community awareness. The basic approaches for hazard evaluation and control are adherence to good safety practices and predictive hazard assessment, periodical safety audits, and inspections. Command and coordination during disasters improve with practice and regular drills involving various stakeholders such as combat team, rescue team, auxiliary team, and those belonging to the community and state authorities.

4.1.2 Preparedness: It refers to those activities carried out before a disaster strikes to dilute the consequences in real situations and comprises of formulating emergency response plans, 
constituting crisis groups, developing infrastructure such as emergency control center, keeping equipment and safety gears ready, acquiring emergency response vehicle, cranes, and battery-operated lights; identifying and building resources, developing effective early warning system, etc.

4.1.3. Emergency response: According to Ramabrahmam et al., 2000; Moe and Pathranarkul, 2006; Good year, 2009 response means activating the On-site and Off-site emergency plan, evaluating consequence in terms of leakage, fire, explosion, heat radiation, overpressure and intoxication and take appropriate corrective measures for control, reduction and transfer of risk; evacuating people; regulating traffic, arranging first aid and medical care, arranging protective gears for first responders, carry out rescue, relief, coordination and networking, and law and order management.

4.1.4. Recovery: It is the process of supporting the affected community in reconstructing their physical infrastructure and restoration of emotional, social, economic, and physical well-being. It includes normalizing traffic, restoration of power and connectivity, neutralization of accident site in case of spillage of hazardous substances, reconstruction of affected infrastructure, restoration of the environment, and addressing psychosocial and livelihood issues of the community.

Mankind never confronted the kind of fear, uncertainty, helplessness, and inadequacy that came with the outbreak of the Covid-19 pandemic. Despite all possible efforts, the virus affected people in 219 countries, killed more than 3 million people, and devastated the world economy. The World Health Organization issued guidelines to enforce mobility restrictions, physical distancing, networking and communication, and hygiene measures to combat and delay the spread of the Covid-19 virus.

4.2.1. Mobility restrictions: The movement of people is restricted to control the spread of the virus by limiting public transportation, use of private transport, regulating outdoor group activities, meetings, and seminars, etc.

4.2.2. Physical distancing: These are social distancing measures aimed at maintaining a distance of 1.5-2m gap between individuals; avoiding groups larger than 2-3 persons and regulating the number of people present per square meter; closing parks, beaches, swimming pools, sports complexes, etc.

4.2.3. Hygiene measures: These are measures aimed to limit contamination by frequent hand washing for 20 seconds, using recommended PPEs such as nose mask, face shield, and hand 
gloves, sneezing in elbows, using hand sanitizers, periodical disinfection of workplace, and taking care during disposal of waste.

4.2.4. Networking and communications: These measures aim at creating user-friendly channels and platforms for communication to win the confidence of the community about the effectiveness of compliance measures. Dedicated web portals, WhatsApp groups, regular press briefing in radio and electronic media by authorized state representatives are good tools for public awareness and neutralize fake news spreaders.

\section{Conclusions}

Consequence management includes all activities and programs which are taken up before, during and after an accident to avoid and reduce the impact. This paper attempts to report on LPG truck tanker accidents and the emergency management during pandemic conditions. The Covid-19 pandemic jeopardized the normal way of life. People were forced to seclusion with series of lockdown, shutdown, and containment measures. The fear of getting infected with the virus affected the regular schedule of mock drills, inspection, and audit activities. The existing emergency response plans did not specify protocols for pandemic scenarios and this was a significant challenge while dealing with hazardous incidents during the lockdown phase. The present study reported on LPG truck tanker accidents and proposed a revised disaster response model for pandemic scenarios.

The study showed that the maximum truck tanker accidents occurred during the night, the highest being during early morning hours between 4.00-800 hours. Cold weather increased the vulnerability with $41 \%$ of cases reported in winter as compared to rainy and summer seasons respectively. The percentage of incidents with the toppling of the tanker was highest (50\%), followed by collision and equipment failure. The rate of accidents during weekdays of Friday-Saturday-Sunday-Monday was more as compared to Tuesday-Wednesday-Thursday. Strengthening the focus on road design, engineering and maintenance, display of safety signage, correction in skill and behavior of drivers, tightening enforcement measures for vehicle fitness, prohibition of drunken driving, ensuring periodical and preventive maintenance of braking, steering and suspension system, training of drivers and transporters, adequate display of road safety, regular checking of fitting and mountings on the bullet, and fixing accountability for lapses shall help in controlling accident rate. 
Transportation of liquefied petroleum gas was never stopped during the lockdown period as it fell under the essential commodity list. With relatively less or no traffic on the road movement of truck tankers was smooth on road. Only two accidents were reported during the pandemic period. While both the accidents were managed successfully yet the challenges in the psychological level were immense due to internal hesitation among certain groups of responders though no one wanted to express this in public. Mock exercises and audits are extremely important and should not be diluted particularly during pandemic situations. Standard operating procedures, response plans, details of emergency crew, technical resources, e-mail ids, details of infrastructure should be uploaded in the public domain so that it is easy to access at the time of need. Setting up emergency response centers in clusters and equipping them with protective gears, flameproof jackets, fire tenders and extinguishers, sanitizers, masks should be taken up on priority. Behavioral issues such as careless and rash driving, drunken driving should be addressed with tight enforcement measures and the use of technology. At the same time, constructing restrooms and food kiosks along highways can be a help to drivers. Further, including road safety and disaster management in academic curriculum, involving drivers in off-site emergency mock drills on national highways, more attention for improvement of emergency medical services, could be considered to strengthen emergency response actions in the larger interest of the public.

Practical Implications: The findings of this study and the recommendations such as enforcement of traffic norms, proper road design, and construction, implementation of SOPs and IEC measures, mock exercises, and revised emergency protocols could be crucial preventive interventions in future.

\section{Declaration of Competing Interest}

The authors declare that they have no known competing financial interests or personal relationships that could have appeared to influence the work reported in this paper.

\section{References}

[1] Al-Dahash, H., Kulatunga, U., \&Thayaparan, M. (2018); Weaknesses during the disaster response management resulting from war operations and terrorism in Iraq. International Journal of Disaster Risk Reduction,doi:10.1016/j.ijdrr.2018.12.003. 
[2] Behera R.K., Hassan M.I., Disaster management using mock drills, Vilakshyan, XIMB Journal of Management, Vol 14 (2017) pp. 51-78.

[3] Behera, R. K., \& Hassan, M. I. (2019); Regulatory interventions and industrial accidents: A case from India for "Vision Zero" goals. Safety Science, 113, pp. 415-424, doi:10.1016/j.ssci.2018.12.013

[4] Bariha, N., Mishra, I. M., \& Srivastava, V. C. (2016). Fire and explosion hazard analysis during surface transport of liquefied petroleum gas (LPG): A case study of LPG truck tanker accident in Kannur, Kerala, India. Journal of Loss Prevention in the Process Industries, 40, 449-460. doi:10.1016/j.jlp.2016.01.020

[5] Binder S, Sanderson LM (1987); The role of the epidemiologist in natural disasters. Annals of Emergency Medicine; 16: pp.1081 -1084.

[6] Brown, C., Milke, M., \& Seville, E. (2011). Disaster waste management: A review article. Waste Management, 31(6), 1085-1098.doi:10.1016/j.wasman.2011.01.027

[7] Bureau of Indian Standards (IS-2825), 1969. Code for Unfired Pressure Vessels. Available at: https://law.resource.org/pub/in/bis/S08/is.2825.1969.pdf. Accessed on 24 February 2021.

[8] Bureau of Indian Standards (IS-9618), 1980. Specification for Road Tanker for Liquefied Petroleum Gas. Available at: ftp://law.resource.org/pub/in/bis/S08/is. 9618.1980.pdf Accessed on 7 April 20201.

[9] Bureau of Indian Standards (IS-4576), 1999. Liquefied Petroleum Gases-specification. Available at: https://law.resource.org/pub/in/bis/S11/is.4576.1999.pdf Accessed on 7 April 2021.

[10] Coleman, L. (2006). Frequency of Man-Made Disasters in the 20th Century. Journal of Contingencies and Crisis Management, 14(1), 3-11.doi:10.1111/j.14685973.2006.00476.x

[11] Deng, J.F., Yang, C.C., Tsai, W.J., Ger, J., Wu, M.L., Acute ethylene chlorohydrin poisonings: experience of a poison control center, Clin. Toxicol. 39 (6) (2001) 587-593.

[12] Gallab, M., Bouloiz, H., Garbolino, E., Tkiouat, M., ElKilani, M. A., \& Bureau, N. (2017). Risk analysis of maintenance activities in a LPG supply chain with a MultiAgent approach. Journal of Loss Prevention in the Process Industries, 47, 4156. doi:10.1016/j.jlp.2017.02.026

[13] GoI. (2005).NDMA, Government of India, The Disaster Management Act, 2005; http://atingl.nic.in/Downloads/THE\%20DISASTER\%20MANAGEMENT\%20

ACT\%202005.pdf. (accessed 24.2.2021) 
[14] Goodyear E.J (2009), The State of Disaster Risk Reduction In Iraq, UNDP/OCHA, New York

[15] Gupta A. K., Nair S S, Chopde S, Singh PK (2010) Policies and strategic options for disaster risk management in India. In: Risk to resilience - strategic tools for disaster risk management. Proceedings of the Intl. Conf. Risk to Resilience, New Delhi, Feb 2009, NIDM, ISET, WII, NOAA, DFID. http://i-s-e-t.org/resources/major-programreports/risk-to-resilience-workshop.html

[16] Hanna, S. R., Strimaitis, D. G., \& Chang, J. C. (1991). Evaluation of fourteen hazardous gas models with ammonia and hydrogen fluoride field data.Journal of Hazardous Materials, 26(2), 127-158, doi:10.1016/0304-3894 (91)80002-6.

[17] Haghani, M., Bliemer, M. C. J., Goerlandt, F., \& Li, J. (2020). The scientific literature on Coronaviruses, COVID-19 and its associated safety-related research dimensions: A scientometric analysis and scoping review. Safety Science, 104806. doi:10.1016/j.ssci.2020.104806

[18] $\mathrm{Hu}$, C.Y., Raymond, D.J., Lessons learned from hazardous chemical incidentsLouisiana Hazardous Substances Emergency Events Surveillance (HSEES) system, J. Hazard. Mater. 115 (2004) 33-38.

[19] Sellami, I., Manescau, B., Chetehouna, K., de Izarra, C., Nait-Said, R., \&Zidani, F. (2018). BLEVE fireball modeling using Fire Dynamics Simulator (FDS) in an Algerian gas industry. Journal of Loss Prevention in the Process Industries, 54, 6984. doi:10.1016/j.jlp.2018.02.010

[20] International Labour Office, Geneva (1993); Major Hazard Control, A practical manual: 1 [Internet]Gas leak from LPG tanker sparks panic in Odisha's Angul;https://kalingatv.com/state/gas-leak-from-lpg-tanker-sparks-panic-in-odishasangul/ . Accessed on 24 February 2021.

[21] [Internet] Accident-prone NH-66 at Vattappara witnesses another LPG tanker mishap; https://timesofindia.indiatimes.com/city/kozhikode/accident-prone-nh-66-at-vattapparawitnesses-another-lpg-tanker-mishap/articleshow/74782614.cms. Accessed on 24 February 2021.

[22] [Internet] Gas tanker topples on $\mathrm{NH} 75$, traffic disrupted; https://www.deccanherald.com/state/gas-tanker-topples-on-nh-75-traffic-disrupted751637.html, Accessed on 24 February 2021. 
[23] [Internet]Departmental Disaster Management plan of Odisha http://dfbodisha.gov.in/sites/default/files/Disaster\%20Mgt.\%20Plan\%20-\%20final.pdf. Accessed on 24 February 2021.

[24] [Internet] Annual activity report of Labour and ESI Department http://labour.odisha.gov.in/LED/Download/AAR-2017_18-English.pdf,Accessed on 24 February 2021.

[25] [Internet] Two dead as truck, LPG Tanker collide and catch fire in Odisha;https://sambadenglish.com/two-dead-as-truck-lpg-tanker-collide-catch-fire-inodisha/.Accessed on 24 February 2021.

[26] [Internet] LPG tanker overturns on NH53 in Odisha, traffic affected; https://kalingatv.com/state/lpg-tanker-overturns-on-nh-53-in-odisha-traffic-affected/ . Accessed on 24 February 2021.

[27] [Internet] Ministry of Petroleum and Natural Gas (MPNG), Govt. Of India. 2017 Available at: http://petroleum.nic.in/sites/default/files/ipngstat_0.pdf. Accessed on 24 February 2021.

[28] [Internet] India becomes world's 2nd largest LPG consumer after government's Ujjawla push; $\quad$ https://economictimes.indiatimes.com/industry/energy/oil-gas/india-becomesworlds-2nd-largest-lpg-consumer-after-governments-ujjawla push/articleshow/67849012.cms?utm_source=contentofinterest\&utm medium=text\&utm campaign $=$ cppst. Accessed on 24 February 2021.

[29] Khanzode V.V., Maiti J., \& Ray P.K.(2012 ) Occupational injury and accident research: A comprehensive review. Safety Science, 50(5), 1355-1367. doi:10.1016/j.ssci.2011.12.015

[30] Kidam, K., Hussin, N. E., Hassan, O., Ahmad, A., Johari, A., \& Hurme, M. (2014). Accident prevention approach throughout process design life cycle. Process Safety and Environmental Protection, 92(5), 412-422. doi:10.1016/j.psep.2014.05.006

[31] Lindell MK, Perry RW, (1996) Addressing gaps in environmental emergency planning: hazardous materials releases during earthquakes. Journal for Environment Planning and Management, 1996;39:529-543.

[32] Liu, Y., Fan, L., Li, X., Shi, S., \& Lu, Y. (2020). Trends of hazardous material accidents (HMAs) during highway transportation from 2013 to 2018 in China. Journal of Loss Prevention in the Process Industries, 104150. doi:10.1016/j.jlp.2020.104150

[33] Moe, T. L. and Pathranarakul, P. (2006). "An integrated approach to natural disaster management: Public project management and its critical success factors", Disaster 
Prevention and Management: An International Journal, Vol. 15 Issue: 3, pp.396-413, https://doi.org/10.1108/09653560610669882

[34] Mojtahedi, M. and LanOo, B. (2017). Critical attributes for proactive engagement of stakeholders in disaster risk management, International Journal of Disaster Risk Reduction, Volume 21, 2017, Pages 35-43, ISSN 2212-4209, https://doi.org/10.1016/j.ijdrr.2016.10.017.

[35] Othman SitiHajar and Beydoun Ghassan, (2013) Model-driven disaster management, $\begin{array}{lllll}\text { Information } \quad \& \quad \text { Management } & 50 \quad \text { (2013) }\end{array}$ https://doi.org/10.1016/j.im.2013.04.002

[36] Patterson, M. W., \& Hoalst-Pullen, N. (2011). Dynamic equifinality: The case of southcentral Chile's evolving forest landscape. Applied Geography, 31(2), 641649. doi:10.1016/j.apgeog.2010.12.004

[37] Ramabrahmam, B. V., Sreenivasulu, B., \&Mallikarjunan, M. M. (1996). Model on-site emergency plan. Case study: Toxic gas release from an ammonia storage terminal. Journal of Loss Prevention in the Process Industries, 9(4), 259265.https://doi.org/10.1016/0950-4230(96)00016-2

[38] Singh, S. K. (2017). Road Traffic Accidents in India: Issues and Challenges. Transportation Research Procedia, 25, 4708-4719. doi:10.1016/j.trpro.2017.05.484

[39] Suruda, A., Wallace, D., Fatal work-related injuries in the U.S. chemical industry 198489, Int. Arch. Environ. Health 68 (1996) 425-429.

[40] Takase, I., Kono, K., Tamura, A., Nishio, H., Dote T., Suzuki K., Case report: Fatality due to acute fluoride poisoning in the workplace, Legal Med. 6 (2004) 197-200

[41] Tran P, Shaw R, Chantry G, Norton J, (2009); GIS and local knowledge in disaster management: a case study of flood risk mapping in Viet Nam; Disasters: 152-69. [Pub Med]

https://peso.gov.in/PDF/AR_2018_19.pdf

[42] Varotsos, C. A., \& Krapivin, V. F. (2020). A new model for the spread of COVID-19 and the improvement of safety. Safety Science, 132, 104962. doi:10.1016/j.ssci.2020.104962

[43] Zhu, C., Zhu, J., Wang, L., \&Mannan, M. S. (2017). Lessons learned from analyzing a VCE accident at a chemical plant. Journal of Loss Prevention in the Process Industries, 50, 397402. doi:10.1016/j.jlp.2017.11.004 
[44] Zimmerman, L. I., Lima, R., Pietrobon, R., \& Marcozzi, D. (2008). The effects of seasonal variation on hazardous chemical releases. Journal of Hazardous Materials, 151(1), 232-238. doi:10.1016/j.jhazmat.2007.05.074. 